


\section{STUDIES ON CHINA}

A series of conference volumes sponsored by the American Council of Learned Societies.

I. The Origins of Chinese Civilization, edited by David N. Keightley, University of California Press, 1982.

2. Popular Chinese Literature and Performing Arts in the People's Republic of China, 1949-1979, edited by Bonnie S. McDougall, University of California Press, 1984.

3. Class and Social Stratification in Post-Revolution China, edited by James L. Watson, Cambridge University Press, 1984 .

4. Popular Culture in Late Imperial China, edited by David Johnson, Andrew J. Nathan, and Evelyn S. Rawski, University of California Press, I985.

5. Kinship Organization in Late Imperial China, 10oo-1940, edited by Patricia Buckley Ebrey and James L. Watson, University of California Press, I986.

6. The Vitality of the Lyric Voice: Shih Poetry from the Late Han to the T'ang, edited by Shuen-fu Lin and Stephen Owen, Princeton University Press, 1986.

7. Policy Implementation in Post-Mao China, edited by David M. Lampton, University of California Press, 1987.

8. Death Ritual in Late Imperial and Modern China, edited by James L. Watson and Evelyn S. Rawski, University of California Press, 1988.

9. Neo-Confucian Education: The Formative Stage, edited by William Theodore de Bary and John W. Chaffee, University of California Press, 1989 .

Io. Orthodoxy in Late Imperial China, edited by Kwang-Ching Liu, University of California Press, 1990.

II. Chinese Local Elites and Patterns of Dominance, edited by Joseph W. Esherick and Mary Backus Rankin, University of California Press, 1990.

12. Marriage and Inequality in Chinese Society, edited by Rubie S. Watson and Patricia Buckley Ebrey, University of California Press, I99I.

13. Chinese History in Economic Perspective, edited by Thomas G. Rawski and Lillian M. Li, University of California Press, r99ı.

14. Bureaucracy, Politics, and Decision Making in Post-Mao China, edited by Kenneth G. Lieberthal and David M. Lampton,

University of California Press, 1992.

15. Pilgrims and Sacred Sites in China, edited by Susan Naquin and Chün-fang Yü, University of California Press, 1992.

16. Ordering the World: Approaches to State and Society in Sung Dynasty China, edited by Robert Hymes and Conrad Schirokauer, University of California Press, 1993.

17. Chinese Families in the Post-Mao Era, edited by Deborah Davis and Stevan Harrell, University of California Press, 1993. 
18. Voices of the Song Lyric in China, edited by Pauline Yu, University of California Press, 1994.

19. Education and Society in Late Imperial China, 160o-19oo, edited by Benjamin A. Elman and Alexander Woodside,

University of California Press, 1994.

20. Chinese Historical Micro-Demography, edited by Stevan Harrell, University of California Press, 1994.

21. The Waning of the Communist State: Economic Origins of Political Decline in China and Hungary, edited by Andrew G. Walder, University of California Press, I995.

22. The Consumer Revolution in Urban China, edited by Deborah S. Davis, University of California Press, 2000.

23. Becoming Chinese: Passages to Modernity and Beyond, edited by Wen-hsin Yeh, University of California Press, 2000.

24. Ways with Words: Writing about Reading Texts from Early China, edited by Peter Bol, Stephen Owen, Willard Peterson, and Pauline Yu, University of California Press, 2000. 



\section{Becoming Chinese}


This volume, and the conference from which it resulted, was supported by the Joint Committee on Chinese Studies of the American Council of Learned Societies and the Social Sciences Research Council, in collaboration with the Academia Sinica Committee on Cooperation in Humanities and Social Sciences. 


\title{
Becoming Chinese
}

Passages to Modernity and Beyond

\author{
EDITED BY \\ Wen-hsin Yeh
}

UNIVERSITY OF CALIFORNIA PRESS

Berkeley Los Angeles London 
University of California Press Berkeley and Los Angeles, California

University of California Press, Ltd.

London, England

C 2000 by

the Regents of the University of California

Library of Congress Cataloging-in-Publication Data

Becoming Chinese : passages to modernity and beyond / Wen-hsin Yeh, editor.

p. $\quad \mathrm{cm}$. - (Studies on China ; 23)

Includes bibliographical references and index.

ISBN 0-520-21923-6 (alk. paper). - ISBN o-520-22218-o (pbk. : alk paper)

I. China-Civilization - 2oth century. 2. Cities and towns-China-

History-2oth century. 3. National characteristics, Chinese.

I. Yeh, Wen-hsin. II. Series.

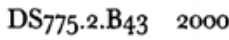

951.05-dc2 I

Manufactured in the United States of America

$\begin{array}{llllllllll}08 & 07 & 06 & 05 & 04 & 03 & 02 & \text { or } & 00 & 99\end{array}$

I0 $\quad \begin{array}{lllllllll}9 & 8 & 7 & 6 & 5 & 4 & 3 & 2 & \text { I }\end{array}$

The paper used in this publication meets the minimum requirements

of ANSI/NISO Z 39-48-1992 (R 1997) (Permanence of Paper). ${ }^{\circledR}$

Chapter 7 is a revised version of materials published as "Sources of Individual and Modern Chinese Identity,"

Chinese Social Sciences Quarterly 9 (November 1994): pp. $5^{1-84}$.

The revised version is reprinted here by permission. 